\title{
The Evaluation of Patients Admitted due to Minor Head Trauma with Clinical Decision Rules
}

\section{Minör Kafa Travması Nedeniyle Başvuran Hastaların Klinik Karar Verme Kuralları Eşliğinde Değerlendirilmesi}

\author{
@ilknur Fidancı'1, @Okşan Derinöz Güleryüz'1, @Elif Çivit ${ }^{2}$ \\ 1 Department of Pediatric Emergency Medicine, Medical Faculty of Gazi University, Turkey \\ ${ }^{2}$ Department of Pediatrics, Medical Faculty of Gazi University, Turkey
}

\begin{abstract}
Aim: We aimed to identify patients admitted to pediatric emergency service due to head trauma using clinical decisionmaking rules.

Material and Method: This is a prospective cohort study involving who referred to a tertiary university hospital pediatric emergency service due to minor head trauma. Evaluations were made with PECARN, CATCH and CHALICE clinical decision rules.

Results: 326 cases were included in the study. $63.5 \%$ (207) of the cases were male, and their ages were $52 \pm 52$ months (min: 1 day max: 214 months). $61.9 \%$ (202) of the cases were admitted due to a fall. $15.3 \%$ (49) cases presenting with minor head trauma had a (computed tomography) CT performed. In cases under the age of three months the CT scan rate was $66.6 \%$, while it was $11 \%$ in cases over three months. $50 \%$ of the cases who had a CT scan satisfied the clinical decision rules. However, two cases who had traumatic brain injury (TBI) in the CT could not be determined with clinical decision rules. There was a statistically significant correlation between the presence of severe mechanism of injury and TBI findings in the $\mathrm{CT}(\mathrm{p}<0,05)$.

Conclusions: In the $\mathrm{CT}$ decision for patients who were admitted with minor head trauma, the role of clinical decision rules is note worthy. In addition, physician experience, the physicians' knowledge of clinical decision rules, the awareness of/raising awareness to the families about the harms of CT and the necessary conditions being provided by hospital observation units for the patients are also essential.
\end{abstract}

Keywords: Minor head trauma, child, CT, PECARN
Öz

Amaç: Minör kafa travması nedeniyle çocuk acil servise başvuran hastaları klinik karar verme kurallarını kullanarak tespit etmeyi amaçladık

Gereç ve Yöntem: Minör kafa travması nedeniyle üçüncü basamak bir üniversite hastanesi çocuk acil servisine başvuran hastaları içeren, Prospektif kohort çalışmadır. PECARN, CATCH ve CHALICE klinik karar verme kurallarıyla hastalar değerlendirildi.

Bulgular: Çalışmaya 326 Olgu dahil edildi. Olguların \%63,5 (207)'i erkek olup, yaşları 52 \pm 52 ay (min: 1 gün-maks: 214 ay) idi. Olguların \%61,9 (202)'u düşme nedeniyle başvurdu. Tüm Bilgisayarlı tomografi(BT) çekilenler, toplam kafa travmalı hastaların \%15,3 (49)'üydü. 3 ay altındaki olgularda BT çekilme oranı \%66,6 iken, üç ay üstünde \%11 idi. BT çekilen olguların \%50'si klinik karar verme kurallarını karşılamaktaydı. Ancak BT'de travmatik beyin hasarı(TBH) olan iki olgu klinik karar verme kurallarıyla saptanamadı. Yüksek enerjili travma varlığı ile BT de TBH bulguları arasında istatistiksel olarak anlamlılık vardı $(p<0,05)$

Sonuç: Minör kafa travmasıyla başvuran hastalarda BT kararında, klinik karar verme kurallarının yeri büyüktür ancak hekim deneyimi, hekimlerin klinik karar verme kurallarını bilmesi, ailelerin BT'nin zararları konusunda bilinçli olması/bilinçlendirilmesi ve hastane gözlem ünitelerinin de bu hastaları gözlemede yeterli koşullara sahip olması gerekmektedir.

Anahtar Kelimeler: Çocuk, minör kafa travması, BT, PECARN 


\section{INTRODUCTION}

Injuries related to trauma are the most frequent cause of mortality in childrenandadolescents worldwide, especially in developed countries. Approximately $40 \%$ of deaths associated with trauma are related to head traumas, and TBI is an important reason formortality and disabilities. ${ }^{[1]}$

Computed tomography (CT) plays a key role in the management of patients with head trauma. However, it is difficult to determine indication in patients with minor head trauma. ${ }^{[2]}$ Minor head trauma is a patient group with a Glasgow Coma Score (GCS) between the 13-15 interval. "Clinically important traumatic brain injury" is seen in \%1 of patients with minor head trauma, and it is important not to skip over this group during the diagnosis. It is also important to determine patients requiring $\mathrm{CT}$ because of the risk of cancer due to radiation. ${ }^{[3]}$

Clinical decision rules help physicians for the decision ofthe requirement of a CT scan in patients with minor head trauma. Of these rules, the most frequently used is the USA based PECARN (The Pediatric Emergency Care Applied Research Network), while the England based CHALICE (The children's head injury algorithm for the prediction of important clinical eventsrule) and Canada based CATCH(Canadian Assessment of Tomography for Childhood Head injury rule) are other frequently used clinical decision rules. ${ }^{[4-7]}$

Our aim was to prospectively review patients who referred to our clinic with minor head trauma in light of clinical decision rules, determine patients with missed traumatic brain injuries by conducting their post-discharge follow-ups and identify our rate of CT use.

\section{MATERIAL AND METHOD}

The study, which was designed as a prospective cohort study, was carried out between the dates 1.6.2017 and 1.6.2018 in a tertiary university hospital in Ankara having an average of 49.000 annual patient admissions to the pediatric emergency service. The ethics committee approval for the study was obtained from the local ethics committee of the Medical Faculty of Gazi University (Decision no: BD2531547422).

Cases with GCS 13-15 who referred to the pediatric emergency service throughout the study due to head trauma were evaluated with the PECARN, CATCH, CHALICE clinical decision rules. The tomography of the cases were evaluated in terms of TBI. Patients who had missed traumatic brain injuries after their discharge were determined.

A study data form was created to record post-discharge monitoring information of the cases such as demographic information, vital signs, GCS, physical examination (PE), clinical states, hospitalization/discharge etc. before the study.

The data form was filled out by the physician evaluating the patient. The physician evaluating the patient made the decision of whether the patient would have a CT scan according to the "clinical decision rules". The decision of the physician was not interfered.

The history and PE findings of the patients required to have a CT scan according to the clinical decision rulesare presented in Table 1. These findings could also be found in our forms.

Traumatic brain injury (TBI) findings in the CT were defined as; skull fracture, pneumocephalus, intracranial hemorrhage or contusion, epidural-subdural hemorrhage, sigmoid sinus thrombosis, traumatic infarction, diffuse axonal injury, herniation findings. ${ }^{[8]}$

Table 1. Decision rules for $\mathrm{CT}$ acquisition in children with minor head injury

\begin{tabular}{|c|c|c|c|c|}
\hline & PECARN $<2$ years & PECARN $\geq 2$ years & CHALICE & CATCH \\
\hline \multicolumn{5}{|l|}{ Historical Variables } \\
\hline Loss of consciousness & $5 \sec \leq$ & $\geq 5 \mathrm{sec}$ & $>5 \mathrm{~min}$ & - \\
\hline Vomiting & - & + & $\geq 3$ & - \\
\hline Headache & - & severe & - & worsening \\
\hline Acting abnormally to parents & + & - & - & - \\
\hline Amnesia & - & - & $>5 \mathrm{~min}$ & - \\
\hline Seizure & - & - & + & - \\
\hline Suspicion of non-accidental injury & - & - & + & - \\
\hline Severe mechanism of injury * & + & + & + & + \\
\hline \multicolumn{5}{|l|}{ Physical Exam Variables } \\
\hline Altered mental status & + & + & - & - \\
\hline Skull fracture & + & \multicolumn{3}{|c|}{ basilar drowsy penetrating, Irritable Open, depressed,basilar depressed or basilar } \\
\hline GCS & $<15$ & $<15$ & $<14^{* *}$ & at 2 hours $<15$ \\
\hline Neurologic deficit & - & - & + & - \\
\hline Scalp hematoma & nonfrontal & - & $5 \mathrm{~cm}<$ & $\begin{array}{c}\text { if 1year }>\text { Large, } \\
\text { Boggy bruises or lacerations }\end{array}$ \\
\hline
\end{tabular}


According tothe "clinical decision rules", the decision was made to discharge or monitoring/hospitalization of the patient. The clinical states of patients who were discharged after the monitoring processwere evaluated by calling them via telephone in the first month and first year of their discharge. Patients were asked if they referred to another hospital after the initial referral, if they had a CT taken, if they developed clinically TBI symptoms (death, staying for at least 2 days in the hospital or requiring intubation for more than 24 hours, brain surgery operation) or traumatic brain injury findings in the $\mathrm{CT}$.

\section{Inclusion Criteria}

All cases under the age of 18 with minor head trauma(who had GCS 13-15), who referred to the pediatric emergency service within the first 24 hours of the incident were included in the study;

\section{Exclusion Criteria}

Cases who had a CT taken in another center before their referral, with an underlying neurological disorder and bleeding disorders, and could not be reached the 1 . and 12 . months of follow-up after their emergency service discharge were not included in the study.

\section{Statistical Analysis}

The data were analyzed with IBM SPSS V23. The conformity to normal distribution was assessed with the Shapiro-Wilk test. The independent and dependent samples t-tests were used in the comparison of independent data with normal distribution and dependent data, respectively. The data conforming to normal distribution are presented as mean \pm standard deviation. For the categorical data comparisons chi-square test and one-way ANOVA testwere used when comparing more than two variables. As for the age comparisons the t-test was used. Analysis results were presented as frequency (percentage) for categorical data, and as averages and standard deviations for numerical data. The significance level was accepted as $\mathrm{p}<0.05$.

\section{RESULTS}

The number of cases evaluated as minor head trauma throughout the study period was 382 (7.8\% of allcases), and 326 cases were included in the study (Figure 1). 63.5\% (207) of the cases forming the study group were male, and their ages were 52 \pm 52 months (min: 1 day - max: 214 months). The average time of referral to the emergency service of the cases after the incident was $2.02 \pm 0.42$ hours. $49.1 \%$ (160) of the casesreferred to the emergency service between 08:00-16:00; and $47.9 \%$ (156) of them referred to the emergency service between 16:00-24:00. The GCS of all cases was 15 at the time of referral. $61.9 \%$ (202) of the cases were admitted due to a fall. There were no signs at the time of referral in $87.8 \%$ (286) of them. The demographic features of all cases with minor head trauma are presented in Table $\mathbf{2}$.
While $97.8 \%$ (319) of the caseswere discharged from the emergency service, $2.1 \%$ (7) of them were hospitalized inpediatric wards. No surgical interventions were performed on any patient included in the study, none of them were admitted to the pediatric intensive care unit and no mortalities were observed in any of the patients.

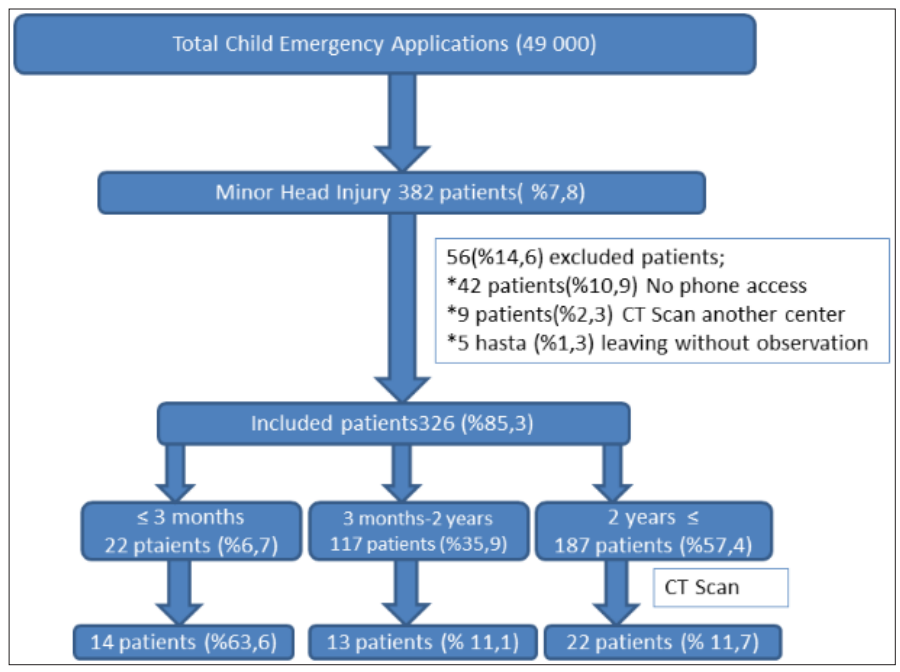

Figure 1. Study flow diagram.

Table 2. Demographic Data of the Cases

\begin{tabular}{|c|c|c|}
\hline & & n (\%) \\
\hline Sex & $\begin{array}{l}\text { Male } \\
\text { Female }\end{array}$ & $\begin{array}{l}207(63.5) \\
119(36.5)\end{array}$ \\
\hline Injury mechanizm & $\begin{array}{l}\text { Fall } \\
\text { Fall of stairs } \\
\text { in-car traffic accident } \\
\text { non-vehicle traffic accident } \\
\text { motorcycle accident } \\
\text { falling of the bike/crashing } \\
\text { assault } \\
\text { head struck by high speed projectile } \\
\text { others }\end{array}$ & $\begin{array}{l}202(61.9) \\
16(4.9) \\
7(2.1) \\
6(1.8) \\
0(0) \\
11(3.4) \\
2(0.6) \\
9(2.8) \\
73(22.4)\end{array}$ \\
\hline The form of trauma & $\begin{array}{l}\text { Isolated head injury } \\
\text { Without isolated head injury }\end{array}$ & $\begin{array}{l}81(24.8) \\
245(75.2)\end{array}$ \\
\hline $\begin{array}{l}\text { Severe mechanism } \\
\text { of injury* }\end{array}$ & $\begin{array}{l}\text { Yes } \\
\text { No }\end{array}$ & $\begin{array}{c}44(13.4) \\
282(86.5)\end{array}$ \\
\hline Symptoms & $\begin{array}{l}\text { No symptom } \\
\text { Vomiting } \\
\text { Severe headache } \\
\text { Loss of consciousness } \\
\text { Amnesia } \\
\text { Seizure }\end{array}$ & $\begin{array}{c}286(87.8) \\
22(6.7) \\
9(2.8) \\
5(1.5) \\
3(0.9) \\
1(0.3)\end{array}$ \\
\hline Physical Exam & $\begin{array}{l}\text { Palpable skull fracture } \\
\text { Temporal hematoma } \\
\text { Occipital hematoma } \\
\text { Parietal hematoma } \\
\text { Frontal hematoma }\end{array}$ & $\begin{array}{l}7(2.1) \\
2(0.6) \\
5(1.5) \\
20(6.1)\end{array}$ \\
\hline $\begin{array}{l}\text { Observation time } \\
\mathrm{n}(\%)\end{array}$ & $\begin{array}{l}0-4 \text { hour } \\
4-8 \text { hour } \\
8-12 \text { hour } \\
12-24 \text { hour } \\
24-48 \text { hour }\end{array}$ & $\begin{array}{l}153(46.9) \\
155(47.5) \\
4(1.2) \\
4(1.2) \\
2(0.6)\end{array}$ \\
\hline $\begin{array}{l}\text { *Severe mechanism define } \\
\text { of passenger, or rollover, } p \\
\text { years and }>1.5 \text { meters if }>2 \\
\text { vehicle collision as occupa } \\
\text { by high speed projectile; a } \\
\text { helmetless bicycle fall. }\end{array}$ & 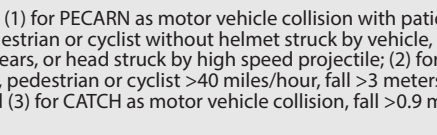 & $\begin{array}{l}\text { jection, death } \\
0.9 \text { meters if }<2 \\
\text { LICE as motor } \\
\text { head struck } \\
\text { s or } 5 \text { stairs, or }\end{array}$ \\
\hline
\end{tabular}


The characteristics according to the age group of the cases who did not have a CT taken are shown in Table 3. When the symptoms and clinical findings that affected the physicians' decision to take aCTwere evaluated, it was observed that physicians decided to take a CT in cases witha history of amnesia (\%100;3 patients ) andseizures (\%100;1 patient), symptoms ofloss of consciousness (\%60;3 patients) andvomiting; who had a temporal, parietal and frontal hematoma.

Table 3. Features of patients without $\mathrm{CT}$, according to their age ranges

\begin{tabular}{|c|c|c|c|}
\hline & $\begin{array}{c}0-3 \\
\text { months }\end{array}$ & $\begin{array}{c}4-24 \\
\text { months }\end{array}$ & $\begin{array}{c}24 \\
\text { months }<\end{array}$ \\
\hline Number of case $\mathrm{n}(\%)$ & $8(2.9)$ & $104(37.5)$ & $165(59.5)$ \\
\hline $\begin{array}{l}\text { Sex } \\
\text { male } \\
\text { female }\end{array}$ & $\begin{array}{l}5 \\
3\end{array}$ & $\begin{array}{l}72 \\
52\end{array}$ & $\begin{array}{l}100 \\
165\end{array}$ \\
\hline $\begin{array}{l}\text { Mechanism of injury } n(\%) \\
\text { fall } \\
\text { fall of stairs } \\
\text { in-car traffic accident } \\
\text { non-vehicle traffic accident } \\
\text { motorcycle accident } \\
\text { falling of the bike/crashing } \\
\text { assault } \\
\text { head struck by high speed projectile } \\
\text { others }\end{array}$ & $\begin{array}{c}5(62.5) \\
- \\
1(12.5) \\
- \\
- \\
- \\
- \\
1(12.5) \\
1(12.5)\end{array}$ & $\begin{array}{c}81(77.8) \\
3(3.9) \\
- \\
- \\
- \\
- \\
1(1) \\
- \\
19(18.3)\end{array}$ & $\begin{array}{c}82(49.6) \\
10(6.1) \\
5(3) \\
3(1.8) \\
- \\
10(6.1) \\
- \\
6(3.6) \\
48(29.1)\end{array}$ \\
\hline Severe mechanism of injury & $2(25)$ & $6(5.7)$ & $26(15.7)$ \\
\hline $\begin{array}{l}\text { Falling height: } \\
<91 \mathrm{~cm} \\
91-150 \mathrm{~cm} \\
>151 \mathrm{~cm}\end{array}$ & $\begin{array}{l}4 \\
- \\
-\end{array}$ & $\begin{array}{l}68 \\
5 \\
-\end{array}$ & $\begin{array}{l}- \\
\overline{2}\end{array}$ \\
\hline $\begin{array}{l}\text { Number of stairs: } \\
<6 \\
6-15 \\
>15\end{array}$ & - & $\begin{array}{l}2 \\
1 \\
-\end{array}$ & $\begin{array}{l}6 \\
4 \\
0\end{array}$ \\
\hline Loss of consciousness & - & 1 & 1 \\
\hline Basilar skull fracture & - & - & - \\
\hline Severe headache & - & 1 & 4 \\
\hline $\begin{array}{c}\text { Vomiting: } \\
<3 \\
>3\end{array}$ & $\begin{array}{l}- \\
- \\
-\end{array}$ & $\begin{array}{l}9 \\
9 \\
-\end{array}$ & $\begin{array}{l}6 \\
6 \\
-\end{array}$ \\
\hline Amnesia & - & - & - \\
\hline Seizure & - & - & - \\
\hline Palpable skull fracture & - & - & - \\
\hline Temporal Hematoma & - & - & 4 \\
\hline Occipital Hematoma & 1 & - & 1 \\
\hline Parietal Hematoma & - & - & 4 \\
\hline Frontal Hematoma & - & 7 & 11 \\
\hline $\begin{array}{l}\text { Lesion size: } \\
\quad<3 \mathrm{~cm} \\
3-5 \mathrm{~cm} \\
>5 \mathrm{~cm}\end{array}$ & $\begin{array}{l}1 \\
- \\
-\end{array}$ & $\begin{array}{l}4 \\
3 \\
-\end{array}$ & $\begin{array}{c}15 \\
4 \\
1\end{array}$ \\
\hline $\begin{array}{l}\text { Observation time } \mathrm{n}(\%) \\
0-4 \text { hour } \\
4-8 \text { hour } \\
8-12 \text { hour } \\
12-24 \text { hour } \\
24-48 \text { hour } \\
48<\text { hour }\end{array}$ & $\begin{array}{c}3(37.5) \\
4(50) \\
- \\
- \\
- \\
-\end{array}$ & $\begin{array}{c}48(46.1) \\
54(52) \\
2(2) \\
- \\
- \\
-\end{array}$ & $\begin{array}{l}91(57) \\
71(43) \\
- \\
- \\
- \\
-\end{array}$ \\
\hline Emergency discharge $n(\%)$ & 7 & $104(100)$ & $162(98)$ \\
\hline Hospitalization n (\%) & - & - & $3(2)$ \\
\hline
\end{tabular}

The relationship between the demographic features of cases who were decided to have a CT scan after the first evaluation and TBI findings in the CT is presented in Table 4. All cases who had a CT taken were $15.3 \%$ (49) of the total cases with head trauma. When the age distribution of the cases having a CT taken was reviewed, it was seen that $44.9 \%$ (22) of the cases were over the age of two.A repeated $\mathrm{CT}$ was required only for $1(0.3 \%)$ child. TBI was seen in $2.1 \%(7)$, of the patients and clinically important TBI findings were not observed in any of the patients.

Patients who had a CT scan according to the clinical decision rules and the presence of findings in their $\mathrm{CT}$ is presented in Table 5.

Patients missed by clinical decision rules are presented in Table 6.

Table 4. The characteristics of CT cases according to their age ranges and their relationship with the presence of TBI in CT

\begin{tabular}{|c|c|c|c|c|}
\hline & $\begin{array}{c}0-3 \\
\text { months }\end{array}$ & $\begin{array}{c}\text { 4-24 } \\
\text { months }\end{array}$ & $\begin{array}{c}24 \\
\text { months }<\end{array}$ & $\mathbf{p}$ \\
\hline Number of case $n(\%)$ & $14(28.5)$ & $13(26.5)$ & $22(44.8)$ & \\
\hline $\begin{array}{l}\text { Sex } \\
\text { Male } \\
\text { Female }\end{array}$ & $\begin{array}{l}11(78.6) \\
3(21.4)\end{array}$ & $\begin{array}{l}7(53.8) \\
6(46.2)\end{array}$ & $\begin{array}{l}12(54.5) \\
10(45.5)\end{array}$ & 0.813 \\
\hline $\begin{array}{l}\text { Mechanism of injury n (\%) } \\
\text { fall } \\
\text { fall of stairs } \\
\text { in-car traffic accident } \\
\text { non-vehicle traffic accident } \\
\text { motorcycle accident } \\
\text { falling of the bike/crashing } \\
\text { assault } \\
\text { head struck by high speed } \\
\text { projectile } \\
\text { others }\end{array}$ & $\begin{array}{c}14(100) \\
- \\
- \\
- \\
- \\
- \\
- \\
- \\
-\end{array}$ & $\begin{array}{c}9(69.2) \\
2(15.3) \\
- \\
- \\
- \\
- \\
- \\
1(7.7) \\
1(7.7)\end{array}$ & $\begin{array}{c}10(63.6) \\
1(4.5) \\
1(4.5) \\
3(13.6) \\
- \\
1(4.5) \\
1(4.5) \\
1(4.5) \\
4(18.2)\end{array}$ & 0.412 \\
\hline Severe mechanism of injury & $1(7.1)$ & $4(30.7)$ & $7(31.8)$ & $0.002^{*}$ \\
\hline $\begin{array}{l}\text { Falling height: } \\
<91 \mathrm{~cm} \\
91-150 \mathrm{~cm} \\
>151 \mathrm{~cm}\end{array}$ & $\begin{array}{c}13(92.9) \\
1(7.1) \\
-\end{array}$ & $\begin{array}{l}5(38.5) \\
1(7.7) \\
1(7.7)\end{array}$ & $\begin{array}{c}- \\
- \\
4(18.2)\end{array}$ & $\begin{array}{c}0.042^{*} \\
0.074 \\
0.008^{*}\end{array}$ \\
\hline $\begin{array}{l}\text { Number of stairs: } \\
<6 \\
6-15 \\
>15\end{array}$ & $\begin{array}{l}- \\
- \\
-\end{array}$ & $2(15.4)$ & 1 (4.5) & ** \\
\hline Loss of consciousness & - & $1(7.7)$ & $2(9.1)$ & ** \\
\hline Basilar skull fracture & - & - & - & ** \\
\hline Severe headache & - & - & $4(18.2)$ & $* *$ \\
\hline $\begin{array}{l}\text { Vomiting: } \\
<3 \\
>3\end{array}$ & $\begin{array}{l}0(0) \\
0(0) \\
0(0)\end{array}$ & $\begin{array}{l}4(30.7) \\
1(7.7) \\
3(23)\end{array}$ & $\begin{array}{l}2(9.1) \\
1(4.5) \\
1(4.5)\end{array}$ & 0.498 \\
\hline Amnesia & - & - & $3(13.6)$ & 0.309 \\
\hline Seizure & - & - & $1(4.5)$ & 0.565 \\
\hline Palpabl skull fracture & - & - & - & ** \\
\hline Temporal Hematoma & $1(7.1)$ & $1(7.7)$ & $1(4.5)$ & 0.713 \\
\hline Occipital Hematoma & - & - & - & $* *$ \\
\hline Parietal Hematoma & - & $1(7.7)$ & - & 0.565 \\
\hline Frontal Hematoma & - & $1(7.7)$ & $1(4.5)$ & 0.411 \\
\hline $\begin{array}{l}\text { Lesion size: } \\
<3 \mathrm{~cm} \\
3-5 \mathrm{~cm} \\
>5 \mathrm{~cm}\end{array}$ & 1 (7.1) & $\begin{array}{l}1(7.7) \\
1(7.7) \\
1(7.7)\end{array}$ & $\begin{array}{c}1(4.5) \\
1(4.5) \\
-\end{array}$ & $\begin{array}{l}0.231 \\
0.525 \\
* *\end{array}$ \\
\hline
\end{tabular}


Table 5. Patients who undergo CT according to clinical decision rules and presence of findings in $\mathrm{CT}$

\begin{tabular}{|c|c|c|c|}
\hline Patients & $\begin{array}{c}\text { Age } \\
\text { (month)/sex }\end{array}$ & $\begin{array}{l}\mathrm{CT} \text { imaging } \\
\text { reason }\end{array}$ & Finding in $\mathrm{CT}$ \\
\hline 1. & $1 / M$ & $* / * *$ & + \\
\hline 2. & 8/M & $* / * * * * * *$ & - \\
\hline 3. & $15 / F$ & $* / * *$ & - \\
\hline 4. & 19/M & $* * *$ & - \\
\hline 5. & 9/M & $* * *$ & + \\
\hline 6. & $13 / F$ & $* * *$ & - \\
\hline 7. & $22 / \mathrm{M}$ & $* * *$ & - \\
\hline 8. & $3,5 / F$ & * & - \\
\hline 9. & $22 / F$ & $* *$ & - \\
\hline 10. & $13 / \mathrm{M}$ & $* *$ & - \\
\hline 11. & 29/M & * & - \\
\hline 12. & $51 / \mathrm{M}$ & $* / * *$ & - \\
\hline 13. & $51 / \mathrm{M}$ & $* / * * *$ & - \\
\hline 14. & $61 / \mathrm{M}$ & $* / * * / * * *$ & + \\
\hline 15. & $66 / F$ & $* / * *$ & + \\
\hline 16. & $69 / F$ & * & - \\
\hline 17. & 78/M & $* * / * * *$ & - \\
\hline 18. & $98 / F$ & $* / * *$ & - \\
\hline 19. & $17 / M$ & $* * / * * *$ & - \\
\hline 20. & $179 / \mathrm{M}$ & $* / * * *$ & - \\
\hline 21. & $179 / \mathrm{M}$ & $* / * * *$ & - \\
\hline 22. & $197 / F$ & $* / * * / * * *$ & + \\
\hline 23. & $194 / F$ & $* * *$ & - \\
\hline 24. & $41 / \mathrm{M}$ & $* *$ & - \\
\hline 25. & $46 / F$ & $* * / * * *$ & - \\
\hline
\end{tabular}

\begin{tabular}{lccc}
\hline $\begin{array}{l}\text { Table 6. Patients who fled according to clinical decision rules } \\
\text { Patients Mechanism of } \\
\text { injury }\end{array}$ & $\begin{array}{c}\text { Age (month)/ } \\
\text { sex }\end{array}$ & $\begin{array}{c}\text { CT imaging } \\
\text { reason }\end{array}$ & $\begin{array}{c}\text { Finding } \\
\text { in CT }\end{array}$ \\
\hline Patient fall of $<90 \mathrm{~cm}$ & $66 / \mathrm{M}$ & $\begin{array}{c}\text { Amnesia } \\
<5 \mathrm{~min}\end{array}$ & + \\
$\begin{array}{l}\text { Patient falling from your } \\
\text { Own height }\end{array}$ & $150 / \mathrm{F}$ & $\begin{array}{c}\text { Temporal } \\
\text { hematoma } \\
<3 \mathrm{~cm}\end{array}$ & + \\
\hline Abbreviation: min: minutes & \multicolumn{3}{c}{} \\
\hline
\end{tabular}

There was a statistically positive relationship between the cases who had an observation duration of 4 hours and more, and the CT rates $(p<0.001)$.

In patients who had a CT scan, the rate of TBI was $14.2 \%$. The TBI finding in all of these patients was a skull fracture. Most of these were seen in 24 months $\leq$.

In patients who had a CT scan, $28.5 \%$ (14) of the patients were under 3 months. All of these patients referred to the hospital due to a fall. $26.5 \%$ (13) of the patients who had a CT taken consisted of 3-24-month old'sand 69.2\% (9) of these patients referred to the hospital due to a fall. $44.8 \%$ (22) of the patients who had a CT taken consisted of $\geq 24$ months, and $63,6 \%$ (10) of these patients referred to the hospital due to a fall (Table 2).
A statistically significant relationship was found between the presence of Severe mechanism of injury and TBI findings in the CTscan $(p<0.05)$ (Table 2). There was a statistically significant relationship between the increase of the falling distance and the presence of findings in the CT $(p<0.05)$ (Table 3$)$. There was not a statistically significant relationship between trauma mechanisms and the presence of findings in the CT scan (Table 3).

The criteria the patients who had a CT taken met in the clinical decision rules are presented in Table 4.

It was learned that none of the patients who were reached via telephone in the first month and the first year after their discharge referred to another hospital due to the same trauma, had a serious TBI and had a CT scan.

\section{DISCUSSION}

Minor head trauma is the most common reason of referral to the pediatric emergency services. ${ }^{[7]}$ In our prospective cohort study where we reviewed patients who referred to our clinic due to minor head trauma, the rate of CT use was $15 \%$. However, when we examined our CT rate according to our patients'age groups, this rate was $63.6 \%$ in the group of under three months and below and \%11 in the group of 4 months and above. We have considered the reasons as to be the difficulty of neurological examination in three-month old patients and insufficient space to admit and observe the patients. As for our overall high $\mathrm{CT}$ rate, we assessed that the reasons for this can be physician experience and foresight, opinion differences among consulting physicians, the request of the families and once again, our observation unit not being adequate for a 24-hour monitoring of these patients.

When the literature was reviewed, in a study in which the multicenter PECARN rules were applied, this rate was 7\%, ${ }^{[8]}$ and in a study in which a pediatric hospital in the United States of America and Italy was compared, the CT rates of patients admitted due tominorhead traumawere $17.3 \%$ and $6.6 \%$, respectively. ${ }^{[9]}$ In another study, the CT rate of patients admitted to a pediatric trauma center due to minor head trauma was \%94.6. ${ }^{[10]}$ As seen in the literature, CT ratescan notably vary according to countries, clinics, and that the clinical decision rules are not used sufficiently. In our study, half of our cases who had a CT scan had a CT indication according to the clinical decision rules as well. The main reason was to be the presence of physicians working in different seniorities in our pediatric emergency service,having different consulting physicians, the requests of the families and the fear of head trauma in minor age groups. Additionally, the clinical decision rules should be clearer for the 3-month-old and younger patient group, where the $\mathrm{CT}$ rates were high in our study.

$\mathrm{TBI}$ is the leading cause of mortality and disability in the world. When the literature was reviewed, clinically important TBI rates were given as $1.1 \%, 5.9 \%$ and $3 \%$ in different studies, respectively. ${ }^{[8,11,12]}$ In our study, being consistent with the 
literature, the TBI rate was $2.1 \%$. All of these were skull fractures and they were mostly 2-year-old or older patients. Clinically important traumatic brain injuries were not observed in any patients. As seen in the literature, while TBI, especially clinically important traumatic brain inquiry is seen quite rarely in patients admitted with minor head trauma, using clinical decision rules in order to not miss these patientsis quite beneficial. Nevertheless, in our study clinical decision rules, 2 patients with TBI were missed. We should apply the rules, but we should not neglect conducting multifaceted evaluations for the patients.

According to the trauma mechanism, the most frequent referral was falling. In a study by Ortega et al., it was found that $53.3 \%$ of the patients who referred to the hospital with head trauma, referred due to high falls as well. ${ }^{[13]}$ In another study, $93 \%$ of children under the age of 3 who presented with minor head trauma presented with a fall. ${ }^{[14]}$

In our study, a significant relationship was determined between referrals with severe mechanism of injurythe presence of findings in the CT scan. In the study conducted with 2-year-old and younger children, a statistically significant relationship was found between the height of the fall, TBI and clinically important $\mathrm{TBI}^{\left[{ }^{[15]}\right.}$ In another study conducted with patients who referred with minorhead trauma, a statistically significant relationship was found between falling from a height $>1 \mathrm{~m}$ and findings inthe CT scan. ${ }^{[16]}$ In our study, being consistent with the literature, a significant relationship was identified between the increase in the distance of the fall and findings in the CT scan as well. A CT scan was taken in most of the patients who were two years old and older and fell from a height over 1.5 meters.

In our study, the most frequent symptom in the history was evaluated as vomiting (6.7\%), followed by severe headaches, loss of consciousness, amnesia, and seizures, respectively. Although, a significant relationship was not found between these symptoms and findings in the CT scan. In a multicentric study, a significant relationship between vomiting and the presence of amnesia, and TBI was found, while a statistically significant relationship with headacheswas not found. ${ }^{[17]}$ In another study vomiting (56.6\%) was the most frequent symptom, followed up by headaches, and a statistically significant relationship was found between headaches and the duration of hospital stay. ${ }^{[18]}$ In another study, a relationship was not be found between the vomiting symptom and TBI findings in the CT. ${ }^{[19]}$ In a study conducted with patients who referred with head trauma, vomiting and headaches were the most frequent symptoms, while a significant relationship was only found between headaches and TBI. ${ }^{[20]}$ As seen in the literature, vomiting is the most frequently seen symptom but the presence of the accompanying symptom, the duration of vomiting, the number of vomiting, its continuation during monitoring should be evaluated entirely. In our study, a significant relationship was not found between the number of vomiting and the presence of $C T$ findings as well.
In a study in the literature, TBI was identified in 9 of 28 patients with temporal hematoma, 2 of the 15 patients with parietal hematoma, 2 of the 22 patients with occipital hematoma. In our study, a CT scan was taken in $42.8 \%$ of the patients with temporal hematoma, $20 \%$ of the patients with parietal hematoma, $10 \%$ of the patients with frontal hematoma. However, a significant relationship was not found between the presence of findings in the $\mathrm{CT}$ and the presence of hematoma. Although hematomas except for the ones in the frontal area are frightening, their existence alone should not be an indication for CT. They should be evaluated with their size and accompanying findings. In our study, a CT scan was taken mostly in patients who were accompanied by severe mechanism of injury or when their lesion size was more than $3 \mathrm{~cm}$.

In a study in the literature, $94 \%$ of the patients were discharged from the pediatric emergency service..$^{[3]}$ In our study, $90 \%$ of the patients were monitored up to about 8 hours, and $97 \%$ of them weredischarged from thepediatricemergency service. We can explain one of the reasons for our high CT rate to be the shortness of our monitoring period.

In our study, the guardians of the patients were called in the 1. month and 12. month, and we determined that they have not referred to a hospital again due to the same trauma, did not have a CTscan taken and did not have a missed TBI. In another study where minor head trauma patients were reviewed,the guardians of the patients were called in the first and third month and have not determined a CT scan due to the same trauma or a missed clinically important TBI. ${ }^{[21]}$

The major limitations of our study were being a singlecentered study, and the patients being evaluated by physicians of different seniorities.

\section{CONCLUSION}

In conclusion, clinical decision rules in the decision of CT scan in patients admissing with minor head trauma are important in the use of CT scan with the correct indication. However, the physicians' knowledge of the clinical decision rules, the awareness of/raising awareness to the families about the harms of CT and the necessary conditions being provided by hospital observation units for monitoring the patients are also essential. Also, for patients who are three months old and younger, clinical decision rules should be clearer and they must be evaluated in a separate category.

\section{ETHICAL DECLARATIONS}

Ethics Commite Approval: The ethics committee approval for the study was obtained from the local ethics committee of the Medical Faculty of Gazi University (Decision no: BD2531547422).

Informed Consent: Because the study was designed retrospectively, no written informed consent form was obtained from patients

Referee Evaluation Process: Externally peer-reviewed. 
Conflict of Interest Statement: The authors have no conflicts of interest to declare.

Financial Disclosure: The authors declared that this study has received no financial support.

Author Contributions: All of the authors declare that they have all participated in the design, execution, and analysis of the paper, and that they have approved the final version.

Acknowledgement: We would like to thank Dr. Osman Demir for his help in statistical analysis of our study.

\section{REFERENCES}

1. Hess EP, Wyatt KD, Kharbanda AB, et al. Effectiveness of the head $C T$ choice decision aid in parents of children with minor head trauma: study protocol for a multicenter randomized trial. Trials 2014;15:253.

2. Larson DB, Johnson LW, Schnell BM, et al. Risinguse of CT in child visit stothe emergency department in the United States, 19952008. Radiology. 2011;259:793-801.

3. Bozan Ö, Aksel G, Kahraman HA, et al. Comparison of PECARN and CATCH clinical decisionrules in children with minör blunt head trauma. Eur J Trauma Emerg Surg 2019;45:849-55.

4. 4.Kuppermann N, Holmes JF, Dayan PS, et al; Pediatric Emergency Care Applied Research Network (PECARN).Identification of children at very low risk of clinically-important brain injuries after head trauma: a prospective cohort study. Lancet 2009;374:1160-70.

5. 5.Dunning J, Daly JP, Lomas JP, et al. Derivation of the children's head injury algorithm for the prediction of important clinical events decision rule for head injury in children. Arch Dis Child 2006;91:885-91.

6. Osmond $\mathrm{MH}$, Klassen TP,Wells GA, et al. CATCH: a clinical decision rule for the use of computed tomography in children with minor head injury. CMAJ 2010;182:341-8

7. 7.Nigrovic LE, Kuppermann N. Children With Minor Blunt Head Trauma Presenting to the Emergency Department.Pediatrics. 2019;144(6).

8. Ide K1, Uematsu S2, Hayano S3, et al. Validation of the PECARN head trauma prediction rules in Japan: A multicenter prospective study. Am J Emerg Med. 2019;158439

9. Stopa BM, Amoroso S, Ronfani L, et al. Comparison of minor head trauma management in the emergency departments of a United States and Italian Children's hospital. Ital J Pediatr. 2019;45:24.

10. Kauffman JD, Litz CN, Thiel SA, et al. To Scan or Not to Scan: Over utilization of Computed Tomography for Minor Head Injury at a Pediatric Trauma Center. J Surg Res 2018;232:164-70.

11. Yıldızhan S, Boyacı MG, Özdinç Ş. How necessary is the computerized brain tomography in minor head trauma? Ulus Travma Acil Cerrahi Derg 2019;25:378-82.

12. Ohbuchi $H$, Hagiwara S, Hirota $K$, et al. Clinical Predictors of Intracranial Injuries in Infants with Minor Head Trauma. World Neurosurg 2017;98:479-83.

13. Ortega HW, VanderVelden $\mathrm{H}$, Reid S. Incidental findings on computed tomography scans in children with mild head trauma. Clin Pediatr 2012;51:872-6.

14. Donnezan D, Delteil C, Moreau E, Bremond V, Boutin A, Bresson V, Tuchtan $\mathrm{L}$, Piercecchi MD. Injuries from alleged accidental minor head trauma in a prospective cohort of children aged 0-3 years in an emergency department. Leg Med (Tokyo). 2021;49:101846.

15. Hughes J, Maguire S, Jones M,et al. Biomechanical characteristics of head injuries from falls in children younger than 48 months. Arch Dis Child. 2016;10:310-5.

16. Andrade FP, Montoro R Neto, Oliveira R,et al. Pediatric minor head trauma: do cranial CT scans change the therapeutic approach? Clinics (Sao Paulo). 2016;71:606-10.

17. Osmond MH, Klassen TP, Wells GA, et al. Validation and refinement of a clinical decision rule for the use of computed tomography in children with minör head injury in the emergency department.; Pediatric Emergency Research Canada (PERC) Head Injury Study Group. CMAJ 2018;190:81622.
18. Jacquet C, Boetto S, Sevely A, et al. Monitoring Criteria of Intracranial Lesions in Children Post Mildor Moderate Head Trauma. Neuropediatrics. 2018;49:385-91.

19. Milliron M, Carlson JN. Do Patients With Minor Head Trauma Require Neuroimaging? Ann Emerg Med. 2016;68:754-5.

20. Güzel A, Hiçdönmez T, Temizöz O, et al. Indications for brain computed tomography and hospital admission pediatric patients with minor head injury: how much can were lyupon clinical findings? Pediatric Neurosurgery. 2009;45:262-70.

21. Lorton F, Poullaouec C, Legallais E,et al.Validation of the PECARN clinical decision rule for children with minor head trauma: a French multicenter prospective study. Scand J Trauma Resusc Emerg Med. 2016;24:98. 